массы, а также влияние изменения степени пенетрации мягкого тела пресноводных моллюсков рода Anodonta в процессе термической обработки на органолептические свойства полуфабриката с его использованием. На основе полученных данных обоснована технология полуфабриката варено-замороженного.

Ключевые слова: пресноводные двустворчатые моллюски рода Anodonta, степень пенетрации мягкого тела, полуфабрикат варено-замороженный.

Golovko Nikolay, Doctor of Technical Sciences, Professor, Department of Commodity Research in Customs Business, Kharkiz
State University of Food Technology and Trade, Ukraine, e-mail: golovko.pal@gmail.com, ORCID: http://orcid.org/0000-0002-1778-4847

Golovko Tatyana, PhD, Associate Professor, Department of Commodity Research in Customs Business, Kharkiv State University of Food Technology and Trade, Ukraine, e-mail: golovko_tn@mail.ru, ORCID: http://orcid.org/0000-0001-7059-3620

Gelikh Anna, Postgraduate Student, Department of Commodity Research in Customs Business, Kharkiv State University of Food Technology and Trade, Ukraine, e-mail: gelihsumy@gmail.com, ORCID: http://orcid.org/0000-0003-3769-1231

\section{Samoichuk K., Poludnenko O., Palyanichka N., Verkholantseva V., Petrychenko 5.}

\title{
EXPERIMENTAL INVESTIGATIONS OF SUGAR CONGENTRATION FOR COUNTERFLOW JET MIXING OF DRINKS
}

Наведені результати експериментального дослідження процесу змішування у протитечійноструминному змішувачі. Отримані залежності кониентрацї сиропу в змішаному розчині від тиску подачі води, напору купажного сиропу, величини кільщевого зазору в приймальній камері $і$ відстані між форсунками. Визначені оптимальні конструктивно-технологічні параметри для забезпечення необхідної кониентрації иукру в готовому розчині при виготовленні солодкого напою «Лимонад».

Ключові слова: струминне змішування, протитечійно-струминний змішувач, змішувач солодких напоїв, перемішування води з купажним сиропом.

\section{Introduction}

In Ukraine, sweet non-alcoholic drinks are in great demand. Today, in the technology of their production, there is a tendency to return to the use of natural raw materials. Previously, drinks were made on the basis of natural juices with the addition of extracts and concentrates of infusions of various collections of medicinal herbs. Thus, in the manufacture of sweet non-alcoholic drinks, one of the main processes is the mixing of fluid components.

Taking into account the growing volumes of production of sweet non-alcoholic drinks, the development and introduction of mixing devices that will ensure high-quality mixing of fluid components with minimum energy and time consumption are relevant.

\section{The object of research and its technological audit}

The object of this research is mixing of fluid components (in particular, water with blend syrup) in the production of sweet non-alcoholic drinks.

Depending on the method of supplying energy to the mixing medium, mixing can be pneumatic, inertial in the fluid flow, circulating, mechanical or jet [1].

Most enterprises use mechanical mixing. For this purpose, devices with a batch mixer are used. The mixing processes in such devices have been fairly well studied. There are many different designs of devices with stirrers.
Technological processes for their manufacture have been developed and their production has been established. Along with these obvious advantages, devices with stirrers have significant disadvantages. To achieve the same technological effect, these devices use more time and energy for mixing than in continuous jet mixers. If in conventional devices the residence time is calculated in minutes, then in continuous devices - in seconds. The degree and efficiency of mixing are very high due to the introduction of considerable power to a small volume.

Jet mixing is the transfer of the kinetic energy of one stream to another stream by direct contact (mixing). Increase of the pressure of the injected stream without direct consumption of mechanical energy is the main, principal property of jet devices. Due to this property, the use of such devices in many branches of production makes it possible to obtain simpler and more reliable technical solutions in comparison with the use of other mixing devices. Therefore, jet mixing was identified as the most effective and promising way of mixing fluid components.

The process of mixing fluids in counterflow-jet mixers is unexplored.

\section{The aim and objectives of research}

The aim of research is the experimental determination of the optimal design and technological parameters of counterflow jet mixing of water with blend syrup to obtain the required sugar concentration in the finished product. 
To achieve this aim it is necessary to:

1. Determine the factors of the process of counterflow jet mixing of drinks and the limits of their variation.

2. Develop an experimental device for studying the counterflow jet mixing and substantiate the methodology of experimental studies.

3. Determine the optimal conditions for production of sweet drink «Lemonade» using sugar-based syrup.

\section{Research of existing solutions of the problem}

Jet mixers have become an alternative to more expensive stirred mixers more than 50 years ago. They have significant advantages over stirred mixers. Jet mixers do not have moving parts, which means they require significantly less maintenance costs. They are much easier to install than mechanical mixers. Stirrers are usually installed in the upper part of the tank, and for this, thicker walls of more durable materials are needed. In biochemical processes, it is desirable to use jet mixers, because they require significantly less maintenance and sterilization costs than mixers with stirred mixers.

Investigation of jet mixing of fluids is a complex process. The establishment of the necessary physical quantities of the mixing process in laboratory conditions is very problematic. Obtaining some process data is completely impossible, therefore, process simulation in ANSYS software is necessary. The results of computer simulation [2-5] and experimental studies [6,7] of jet mixing of fluids in the reservoir are presented in the analyzed papers. The results of experimental investigations confirm the correctness of the dependencies obtained during the process simulation in the software complex.

Counterflow jet mixing is one of the types of jet mixing. When developing the design of the counterflow jet mixer, computer simulation of the process in the mixer is also applied.

In scientific and practical works [8-12], various designs of jet mixers are presented, which can be used in the production of sweet non-alcoholic drinks.

Among the designs of jet mixers, the most effective are:

- hydrodynamic mixer [10];

- multi-cone jet device [12].

The advantage of the hydrodynamic mixer is the high mixing capacity with a fairly simple design. The disadvantage is the need to pre-connect the components in the tank to ensure the required concentration of the solution, that is, when making drinks, it will work as a batch mixer.

The multi-cone jet device ensures high-quality mixing of fluids and allows to regulate the amount of admixed component with high accuracy. But it has a more complex design (and therefore less reliability) than a hydrodynamic mixer. Also energy costs are excessive

For various designs of jet mixers, experimental investigations have been carried out and a large number of dependencies have been determined, but these dependences are not universal and can't be used for any jet mixer.

Currently, the most explored is the process of jet mixing in a tank. Concerning the manufacture of sweet non-alcoholic drinks, mixing in the tank has a number of disadvantages. Such mixture has a periodic character. Intensive mixing of components occurs only in one zone, close to the nozzle of the mixer. Mixing occurs with much less intensity in all other zones. To ensure homogeneity of the mixture (solution concentration) through the tank, multiple passage of the fluid through the zone of intensive mixing is necessary. This leads to undesirable energy and time for mixing.

This article is an integral part of the series of articles devoted to jet mixing of fluid components. In previous articles, the method of mixing was substantiated [13]. The design of the mixing device is presented, the design features of which are protected by the patent of Ukraine for the utility model [14]. A method for estimating the mixing quality was determined [15]. In the software complex ANSYS Workbench, the process of mixing fluids in the developed mixer was simulated and the distance between the injector of the nozzles was theoretically determined (one of the most important design parameters) [16].

Due to a large number of factors and the lack of a priori information about the object of the research, a search experiment was conducted [17]. The results of the experiment made it possible to determine the optimum range of variation of the factors of the main experiment: the supply pressure of the main component (water) is $1.2-5 \mathrm{~atm}$; supply pressure of the admixed component (blend syrup) is $0.3-0.5 \mathrm{~m}$; distance between the injectors of the nozzles is $16-24 \mathrm{~mm}$.

\section{Methods of research}

As a result of previous analytical investigations of existing jet mixers [13], a counterflow jet mixer was developed [14].

The scheme of the developed mixer design is shown in Fig. 1.

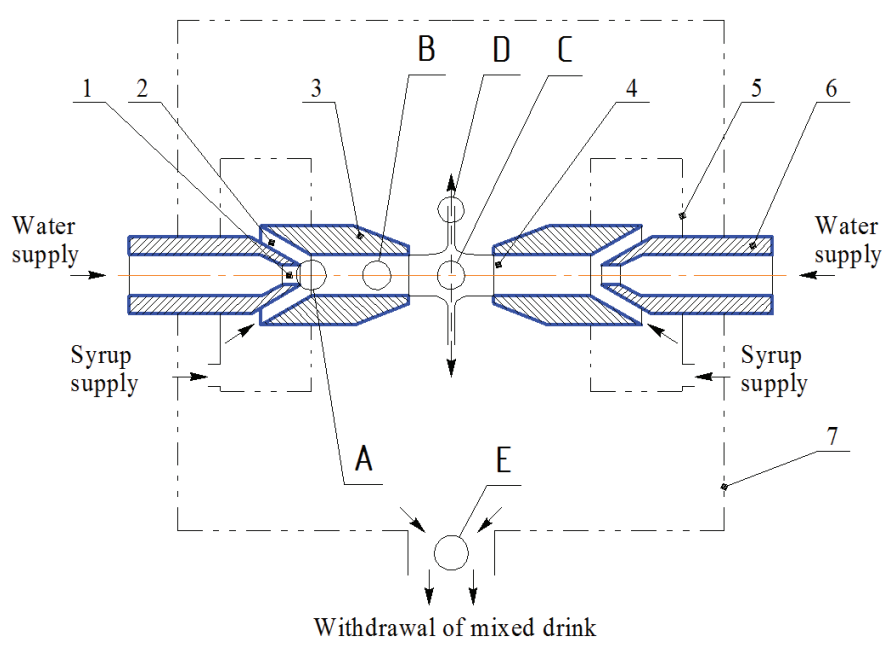

Fig. 1. Scheme of a counterflow jet mixer for fluids: 1 - working nozzle; 2 - receiving chamber; 3 - mixing chamber; 4 - mixing chamber nozzle; 5 - syrup supply chamber; 6 - working connection pipe; 7 - fluid collection chamber. A, B, C, D, E - mixing zones

The mixer consists of two jet devices arranged coaxially to each other (Fig. 1). The exit cylindrical nozzles of these devices form counter-streams of water, which after collision form a characteristic, visually symmetrical «fan», which is called a spray [18]. The coaxial jet devices are 
located in the chamber 7 , where fluid is collected and discharged from the mixer.

Each jet device consists of a working connection pipe 6 and a mixing chamber 3 . The main component (water) is supplied into the working connection pipe of each jet device, the working nozzle 1 of which forms jets of water. The admixed component (syrup) is supplied from the syrup supply chambers (5) to the clearance of the intake chamber 2. High-speed water flows at the inlet of the mixing chamber capture the admixed component. In the mixing chamber, velocities of the water and the admixed component are equalized. At the exit from the nozzles of mixing chambers 4, jets of mixed components collide.

Mixing starts with the inlet of the mixing chamber and occurs continuously until the mixture leaves the mixer. This process takes place most intensively when the admixed component is captured by water, and also when the flow is formed in the mixing chamber (zone A) and when moving in the mixing chamber (zone B). In these zones, mixing of water and the admixed component takes place, which are supplied into one jet device. When the flows (zone C) collide, mixing in the spray (zone D) and collecting fluid and withdrawing from the collection chamber (zone E), the flows of components of the right and left jet devices are mixed.

The main factor of mixing in zones $\mathrm{A}$ and $\mathrm{B}$ is the turbulence and turbulent pulsations of fluids of the main and admixed components. In zones $\mathrm{C}, \mathrm{D}, \mathrm{E}$, mixing occurs due to interpenetration of flows, jets and layers of components.

To carry out experimental studies of mixing of water with blend syrup, an experimental device is developed and manufactured. A general view of the experimental device is shown in Fig. 2.

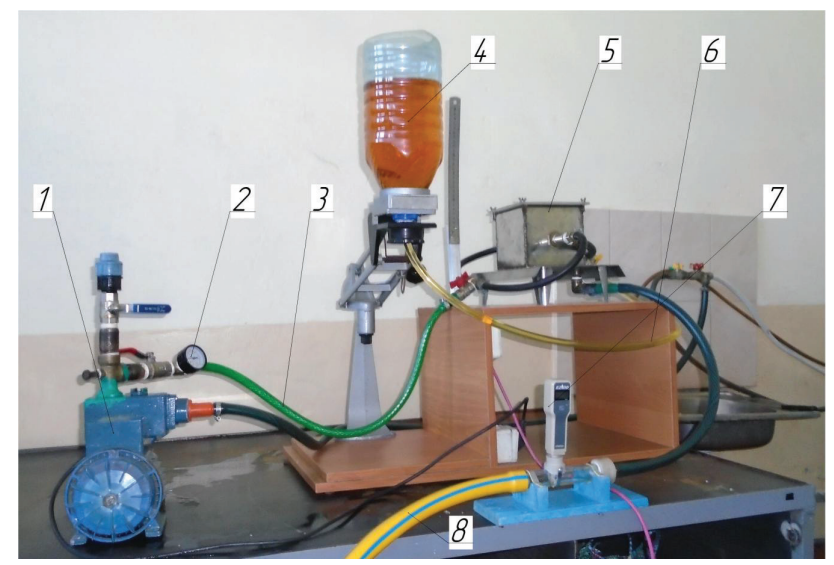

Fig. 2. Experimental device: 1 - vortex pump; 2 - manometer; 3 - channel for supply of the main component (water); 4 - tank with admixed component (syrup); 5 - counterflow jet mixer; 6 - channel for supply of the admixed component; 7 - conductometer; 8 - channel for withdrawal of the mixed product

In Fig. 2, the vortex pump 1 creates the required supply pressure of the main component. The pressure is controlled by means of a pressure manometer 2 . The water enters the counterflow jet mixer 5 through the channel for supply of the main component 3 . The admixed component enters the mixer from the tank 4 through the supply channel 6. After mixing in the counterflow jet mix, the mixed product is removed through the channel 8 .

Taking into account the results of analytical studies and a search experiment [17, 18], the following limits of factor variation were determined for carrying out the main experiment:

- distance between the injectors of the nozzles (lower limit is $8 \mathrm{~mm}$, upper $-24 \mathrm{~mm}$, step of factor change $-8 \mathrm{~mm}$ );

- water supply pressure (lower limit - $0.12 \mathrm{MPa}$, upper $-0.36 \mathrm{MPa}$, step of factor change $-0.12 \mathrm{MPa}$ );

- blend syrup supply pressure (lower limit - $150 \mathrm{~mm}$, upper $-450 \mathrm{~mm}$, the step of factor change is $150 \mathrm{~mm}$ ).

Experimental studies were carried out according to the following procedure: the basis (tap water GOST 2874-82) at a temperature of $20^{\circ} \mathrm{C}(293 \mathrm{~K})$ and density of $1000 \mathrm{~kg} / \mathrm{m}^{3}$ is supplied into the ejector under pressure. When passing through the ejector, the kinetic energy of the water flow increases, and the potential energy decreases to create a vacuum, reaches a maximum value at the point of the greatest narrowing of the flow, that is, at the exit from the ejector. Mixing syrup «Lemonade», based on sugar $20{ }^{\circ} \mathrm{C}(293 \mathrm{~K})$ and density of $1229 \mathrm{~kg} / \mathrm{m}^{3}$ at atmospheric pressure $(0.1 \mathrm{MPa})$ is supplied into the mixing chamber of the admixed component.

When a water stream passes through the mixing chamber of the admixed component, blend syrup is ejected into the water flow. When the jet passes through the nozzle, the primary component is premixed with the admixture, and when the jets collide, final mixing of the fluid components takes place.

The size of the receiving chambers is changed by the axial movement of the working nozzles and during the investigation the dimensions of both chambers are fixed the same. The distance between the injectors of the nozzles is changed by the axial movement of the nozzles in the guide sleeves.

The water supply pressure is created by means of a vortex pump (manufacturer KENLE, China, $H_{\max }=50 \mathrm{~m}$, $Q_{\max }=50 \mathrm{l} / \mathrm{min}$ ). The pressure changes with a rotating crane. The control of the water supply pressure to the mixer is carried out using the МПЗ-У manometer, Russia. According to GOST 2405-88 the measurement limits are $0-10 \mathrm{kgf} / \mathrm{cm}^{2}(0-1.0 \mathrm{MPa}), 0.2 \mathrm{~atm}$.

Blend syrup pressure when it is supplied into the receiving chamber is changed by setting the container with the blend syrup at the required height relative to the axis of the mixer nozzles.

Determination of the concentration of blend syrup in a mixed solution is carried out with the aid of a hydrometer-saccharometer AC-3, Ukraine (GOST 18481-81, $0-25 \%, 0.5 \%)$.

\section{Research results}

According to the instructions, sugar concentration in the ready-made drink «Lemonade» should be $9.5 \pm 0.2 \%$.

Dependences of the change in sugar concentration on the water supply pressure at the blend syrup supply pressure of $150-450 \mathrm{~mm}$ and the magnitude of the annular clearance in the receiving chamber of $0.9 \mathrm{~mm}$ are shown in Fig. 3 . They show that at a water supply pressure of $1.2 \mathrm{~atm}$. and a blend syrup supply pressure of $150 \mathrm{~mm}$, syrup concentration in the resulting solution is the same $-3.5 \%$. 


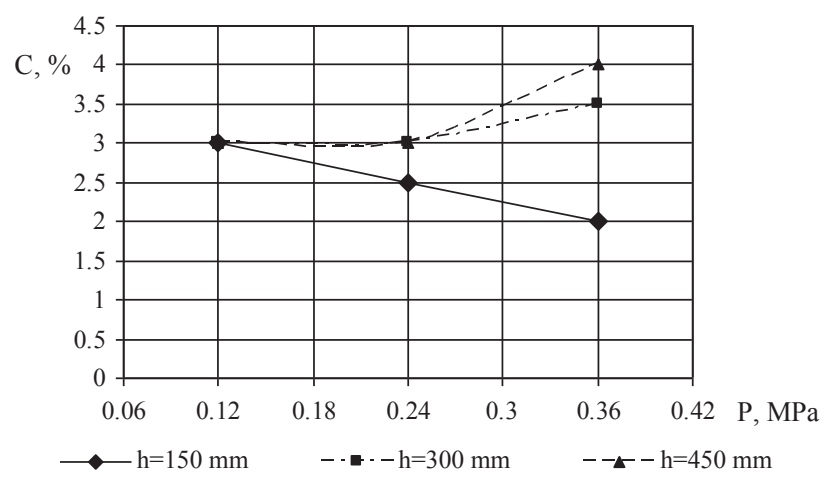

Fig. 3. Dependence of syrup concentration $C$ in a mixed solution on the water supply pressure $\mathrm{P}$ at a blend syrup supply pressure of 150-450 $\mathrm{mm}$ and the annular clearance in the receiving chamber of $0.9 \mathrm{~mm}$. The injector nozzle diameter is $8 \mathrm{~mm}$, the distance between nozzles is $24 \mathrm{~mm}$

For blend syrup supply pressure of $150 \mathrm{~mm}$, with increasing supply pressure of the main component - water, the share of the syrup in the solution decreases. This is due to the increase in water supply to a greater extent than the increase in blend syrup supply pressure, which leads to a decrease in its concentration in the finished solution (from 3.5 to $2 \%$ ).

For blend syrup supply pressure more than $300 \mathrm{~mm}$, with increasing water supply pressure, syrup concentration in the solution increases. For this syrup pressure, the amount of syrup injected into the solution increases with increasing pressure of the water supply (the amount of syrup captured by the main stream increases with increasing water supply) - from 3.5 to $4 \%$.

For blend syrup supply pressure of $450 \mathrm{~mm}$, syrup concentration in the finished solution increases more intensively, from 3.5 to $4.5 \%$.

But this concentration of syrup in the finished solution is too low for the sweet drink «Lemonade».

Dependences of the concentration change on the water supply pressure at the blend syrup supply pressure of $150-450 \mathrm{~mm}$ and the annular clearance in the receiving chamber of $1.8 \mathrm{~mm}$ are shown in Fig. 4. They show that with the increase in supply pressure of the main component and the increase in pressure, the concentration of the admixed component in the finished solution increases. This dependence is close to linear. This indicates that the value of the $1.8 \mathrm{~mm}$ annular clearance is sufficient for the functioning of the ejection unit in the research range of blend syrup supply pressure in the normal mode.

For the pressure changes from 150 to $450 \mathrm{~mm}$, the concentration increases from 8.5 to $10 \%$ (by $16 \%$ ), and when a pressure increases from 1.2 to 3.6 atm. - by $40 \%$. That is, the effect of the water supply pressure produces a more significant contribution than blend syrup supply pressure.

This syrup concentration in the finished solution is sufficient to make a sweet drink «Lemonade». Ensuring the required concentration is possible by adjusting the water supply pressure, the clearance in the feed chamber of the admixed component or blend syrup supply pressure.

Dependences of the change in the syrup concentration on the supply pressure of water to the annular clearance in the receiving chamber of $2.7 \mathrm{~mm}$ are shown in Fig. 5 . They show that when the supply pressure of the main component increases, the concentration of the admixed component in the finished solution decreases.

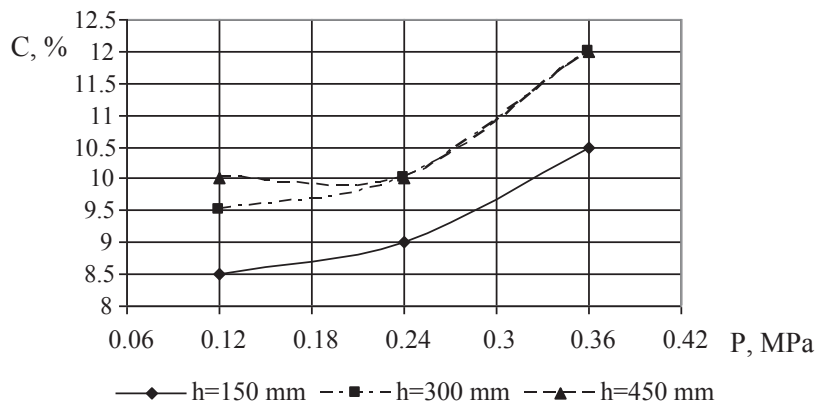

Fig. 4. Dependence of syrup concentration $C$ in a mixed solution on the water supply pressure $P$ at a blend syrup supply pressure of 150-450 mm and the annular clearance in the receiving chamber of $1.8 \mathrm{~mm}$. The injector nozzle diameter is $8 \mathrm{~mm}$, the distance between nozzles is $24 \mathrm{~mm}$

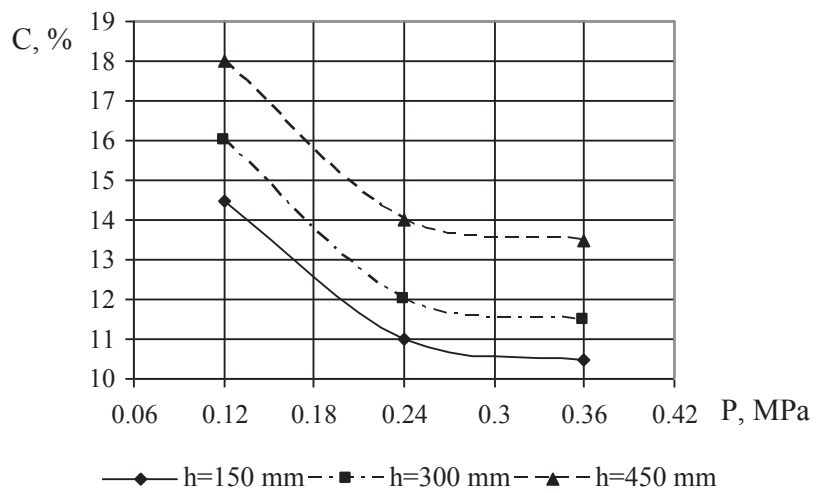

Fig. 5. Dependence of syrup concentration $C$ in a mixed solution on the water supply pressure $\mathrm{P}$ at a blend syrup supply pressure of 150-450 mm and the annular clearance in the receiving chamber of $2.7 \mathrm{~mm}$. The injector nozzle diameter is $8 \mathrm{~mm}$, the distance between nozzles is $24 \mathrm{~mm}$

The high values of the syrup concentration in the finished solution are due to the increased clearance of the admixed component in the feed chamber.

As the supply pressure of the main component increases, the velocity of the flow increases. Two co-axial jets from the nozzles collide, which leads to an increase in the pressure in the collision zone. Therefore, the pressure differential $\Delta \mathrm{p}$ decreases, this leads to a decrease in the injection coefficient.

Analysis of the dependencies in accordance to the results of the experimental studies shows that the optimal conditions for the production of a sweet drink «Lemonade» using sugar syrup (50\%) and injector nozzle diameter of $8 \mathrm{~mm}$, are:

- distance between nozzles is $24 \mathrm{~mm}$;

- blend syrup supply pressure is $200-450 \mathrm{~mm}$;

- water supply pressure is $3.5-4 \mathrm{~atm}$.

The obtained data are the necessary basis for further research and design of experimental samples of a counterflow jet mixer for drinks. They can also be useful in the development of counterflow jet mixers for fluid components in other branches of the national economy. 


\section{SWOT analysis of research results}

Strengths. Among the strengths of this research, it should be noted that the influence of almost all factors influencing the mixing process is investigated simultaneously:

- water supply pressure;

- blend syrup supply pressure;

- the value of the annular clearance in the receiving chamber;

- distance between nozzles.

The influence of the latter factor is extremely difficult to determine with the help of analytical studies.

The introduction of continuous counterflow jet mixers in production will significantly reduce the cost of production of sweet drinks.

Compared to batch machines (devices with stirrers, jet mixers for mixing in a tank), counterflow jet mixers have a significantly lower energy and material consumption. Their dimensions are much smaller.

Counterflow jet devices are more reliable than those with agitators. This is due to the lack of moving parts. Due to the simplicity of design, they are much cheaper and easier to maintain.

Unlike jet mixers in the tank, counterflow jet mixers have a continuous mode of operation. At much smaller dimensions, more intensive mixing is provided.

Weaknesses. The weaknesses of this research are related to the mismatch of the temperature characteristics of the miscible fluids. In the production of sweet carbonated soft drinks, water is cooled to $4{ }^{\circ} \mathrm{C}$ for a better dissolution in the carbon dioxide drink, and the experimental studies are carried out at a water temperature of $20^{\circ} \mathrm{C}$.

In the future, it is necessary to investigate the effect of the temperature of the miscible components on the mixing process. It is also necessary to investigate the mixing quality in a counterflow jet mixer.

Although today there is a return to the production of sugar-based drinks (which is a healthier product), yet the vast majority of sugary drinks are made on the basis of sweeteners. The use of sweeteners such as aspartame, saccharin, etc., renders the drink concentrate (i. e., the admixed component) other physical properties. For example, sweetener-based concentrate has a much lower density than sugar blend syrup. Therefore, further research is needed to determine the design and technological parameters of the counterflow jet mixer for making sweetener-based drinks.

Opportunities. Mixing of fluid components is a widely used technological process in many branches of the national economy. Research results can be useful in the development of counterflow jet mixers for fluid components for other industries (for example, for the preparation of mother liquors used in crop production and animal husbandry, etc.). With the introduction of such mixer in production, the cost of production will decrease and the productivity of the technological line for production of drinks will increase. This will be due to increased productivity and reduced energy costs.

Threats. Significant threats in introducing the research results into production are not foreseen, but complications are possible in the production lines of drinks where the blade stirrers are used. They can be associated with:

- fundamental change in the mixing principle in new equipment;
- need to harmonize the productivity of the developed jet mixer with the performance of the previous device in the drink production line;

- possibility of increased foam formation when using certain types of natural raw materials in the formulation of drinks;

When introducing a counterflow jet mixer, the company will incur additional costs associated with:

- need to install additional coarse filters before the jet mixer, which are necessary for the stable functioning of the developed device;

- possible need to establish an automated system for monitoring and controlling the syrup content in drinks.

Thus, SWOT analysis of research results allows to identify the main directions for the successful achievement of the research aim. They are:

- determination of the quality of mixing fluids in a counterflow jet mixer;

- determination of constructive and technological parameters of the mixer when mixing of water with sweetener-based concentrate;

- determination of the temperature influence on the mixing quality of fluid components in a counterflow jet mixer.

\section{Conclusions}

1. The factors of the process of counterflow jet mixing of drinks and the range of their variation are determined:

- distance between injector of nozzles $(8-24 \mathrm{~mm})$;

- water supply pressure $(0.12-0.36 \mathrm{MPa})$;

- blend syrup supply pressure (150-450 mm);

- clearance in the receiving chamber $(0.9-2.7 \mathrm{~mm})$.

2. An experimental device has been designed and manufactured that allows to investigate the influence of the main factors on syrup concentration in the finished product. The technique of experimental studies of mixing of water with blend syrup in a counterflow jet mixer is substantiated and the necessary measuring equipment is selected.

As a result of the analysis of the obtained experimental data, it is determined that the distance between the nozzles is a significant factor in the effect on the sugar concentration in the mixed product. The least impact is the blend syrup supply pressure. There is a very close connection between such factors as the clearance in the receiving chamber and the water supply pressure. The reason for this is an increase in the pressure in the collision zone of coaxial jets, which leads to decrease in the pressure drop at the inlet and outlet of the nozzles and, consequently, to decrease in the injection coefficient.

It is determined that the optimal conditions for the production of a sweet drink «Lemonade» using sugar syrup (50\%) and injector nozzle diameter of $8 \mathrm{~mm}$, are:

- distance between nozzles is $24 \mathrm{~mm}$;

- blend syrup supply pressure is $200-450 \mathrm{~mm}$;

- water supply pressure is $3.5-4 \mathrm{~atm}$.

The obtained data are the necessary basis for further research and design of experimental samples of a counterflow jet mixer for drinks. They can also be useful in the development of counterflow jet mixers for fluid components in other branches of the national economy. 


\section{References}

1. Landau, L. D. Teoreticheskaja fizika [Text]. Vol. VI. Gidrodinamika / L. D. Landau, E. M. Lifshic. - Moscow: FIZMATLIT, 2001. - $731 \mathrm{p}$

2. Wasewar, K. L. CFD Modelling and Simulation of Jet Mixed Tanks [Text] / K. L. Wasewar, J. V. Sarathi // Engineering Applications of Computational Fluid Mechanics. - 2008. Vol. 2, № 2. - P. 155-171. doi:10.1080/19942060.2008.11015218

3. Sendilkumar, K. Computational fluid dynamic analysis of mixing characteristics inside a jet mixer for newtonian and non newtonian fluids [Text] / K. Sendilkumar, P. Kalaichelvi, M. Perumalsamy, A. Arunagiri, T. Raja // Proceedings of the World Congress on Engineering and Computer Science. - 2007. - 9 p.

4. Saravanan, K. Studies on some aspects of jet mixers I: Hydrodynamics [Text] / K. Saravanan, N. Sundaramoorthy, G. Mohankumar, N. Subramanian // Modern Applied Science. - 2010. Vol. 4, № 3. - P. 51-59. doi:10.5539/mas.v4n3p51

5. Wasewar, K. L. A design of jet mixed tank [Text] / K. L. Wasewar // Chemical and Biochemical Engineering Quarterly. 2006. - Vol. 20, № 1. - P. 31-46.

6. Pan, G. Experimental study of turbulent mixing in a tee mixer using PIV and PLIF [Text] / G. Pan, H. Meng // AIChE Journal. 2001. - Vol. 47, № 12. - P. 2653-2665. doi:10.1002/aic.690471205

7. Daas, M. Submerged Jet Mixing in Nuclear Waste Tanks: A Correlation for Jet Velocity [Text] / M. Daas, R. Srivasta, D. Roeltan // WM Symposia. - 2007. - Vol. 41, № 14. - 9 p.

8. Engelbrecht, J. J. Optimization of a Hydraulic Mixing Nozzle [Text] / J. J. Engelbrecht. - Iowa State University, 2007. - 65 p.

9. Espinosa, E. Design Optimization of Submerged Jet Nozzles for Enhanced Mixing [Text] / E. Espinosa. - Florida International University, 2011. - $101 \mathrm{p}$.

10. Gidrodinamicheskii smesitel' [Text]: Patent № 2016641 RU Piatkov M. V. - Appl. № 4786991/26; Filed 09.11.1989; Publ. 30.07.1994, Bull. № 27. - 3 p

11. Smesitel' [Text]: Patent № 2040322 RU / Egorov Yu. V., Belykh V. S. - Appl. № 5042290/26; Filed 15.05.1992; Publ. 25.07.1995, Bull. № 24. - 4 p.

12. Mnogokonusnyj strujnyj apparat [Text]: Patent № 2080164 RU / Borodin V. A. - Appl. № 93015447/25; Filed 24.03.1993; Publ. 27.05.1997, Bull. № 20. - 3 p.

13. Samoichuk, K. O. Analiz obladnannia dlia peremishuvannia ridkykh komponentiv [Text] / K. O. Samoichuk, O. V. Poludnenko // Pratsi Tavriiskoho derzhavnoho ahrotekhnolohichnoho universytetu: naukove fakhove vydannia. - 2011. - Vol. 11, № 6. - P. 226-233.

14. Samoichuk, K. O. Obosnovanie konstruktsii smesitelia zhidkih komponentov s pomoshch'iu komp'iuternogo modelirovaniia [Text] / K. O. Samoichuk, O. V. Poludnenko // Materialy VII Mezhdunarodnoi nauchno-prakticheskoi konferentsii «Aktual'nye problemy nauchno-tehnicheskogo progressa v APK», 20-22 marta 2013 g., g. Stavropol. - Stavropol: SGAU, 2013. - P. 86-92.

15. Tsyb, V. H. Analiz metodiv otsiniuvannia yakosti zmishuvannia ridkykh komponentiv pry vyrobnytstvi bezalkoholnykh napoiv [Text] / V. H. Tsyb, O. V. Poludnenko // Pratsi Tavriiskoho derzhavnoho ahrotekhnolohichnoho universytetu: naukove fakhove vydannia. - 2014. - Vol. 14, № 1. - P. 7-12.
16. Samoichuk, K. O. Vyznachennia vidstani mizh soplamy forsunok protytechiino-strumynnoho zmishuvacha bezalkoholnykh napoiv [Text] / K. O. Samoichuk, O. V. Poludnenko, V. H. Tsyb // Pratsi Tavriiskoho derzhavnoho ahrotekhnolohichnoho universytetu: naukovo-fakhove vydannia. - 2015. - Vol. 15, № 1. - P. 30-38.

17. Samoichuk, K. O. Eksperymentalne vyznachennia kontsentratsii syropu u protytechiino-strumynnomu zmishuvachi [Text] / K. O. Samoichuk, V. V. Panina, O. V. Poludnenko // Materialy XVI Mizhnarodnoi naukovoi konferentsii «Udoskonalennia protsesiv i obladnannia kharchovykh ta khimichnykh vyrobnytstv», 5-9 veresnia 2016 r., m. Odesa. - Odesa: ONAKhT, 2016. - P. 327-331.

18. Mayer, I. Simple Theorems, Proofs, and Derivations in Quantum Chemistry [Text] / I. Mayer. - Springer US, 2003. - 337 p. doi:10.1007/978-1-4757-6519-9

\section{ЭКСПЕРИМЕНТАЛЬНЫЕ ИССЛЕДОВАНИЯ КОНЦЕНТРАЦИИ САХАРА ПРИ ПРОТИВОТОЧНО-СТРУЙНОМ СМЕШИВАНИИ HAIKTKOB}

Приведены результаты экспериментального исследования процесса смешивания в противоточно-струйном смесителе. Получены зависимости концентрации сиропа в смешанном растворе от давления подачи воды, напора купажного сиропа, величины кольцевого зазора в приемной камере и расстояния между форсунками. Определены конструктивно-технологические параметры для обеспечения необходимой концентрации сахара в готовом растворе при изготовлении сладкого напитка «Лимонад».

Ключевые слова: струйное смешивание, противоточно-струйный смеситель, смеситель сладких напитков, перемешивание воды с купажным сиропом.

Samoichuk Kyrylo, PhD, Associate Professor, Department of Processing and Food Production Equipment, Tavria State Agrotechnological University,Ukraine, e-mail: samanya_kir@mail.ru, ORCID: http:// orcid.org/0000-0002-3423-3510

Poludnenko Olga, Assistant, Department of Processing and Food Production Equipment, Tavria State Agrotechnological University, Ukraine, e-mail: vyunik.olga@gmail.com, ORCID: http://orcid.org/ 0000-0002-6413-5567

Palyanichka Nadiya, PhD, Senior Lecturer, Department of Processing and Food Production Equipment, Tavria State Agrotechnological University, Ukraine, e-mail: palyanichkan@gmail.com, ORCID: http://orcid.org/0000-0001-8510-7146

Verkholantseva Valentyna, PhD, Senior Lecturer, Department of Processing Equipment and Food Industries, Tavria State Agrotechnological University, Ukraine, e-mail: milaeva.v@mail.ru, ORCID: http://orcid.org/0000-0003-1961-2149

Petrychenko Serhii, PhD, Associate Professor, Department of Processing Equipment and Food Industries, Tavria State Agrotechnological University, Ukraine, e-mail:psv-62@mail.ru, ORCID: http://orcid.org/ 0000-0003-3424-5316 